\title{
Cardiac work and myocardial substrate extraction in congestive cardiomyopathy
}

\author{
D S THOMPSON, N NAQVI, S M JUUL, R H SWANTON, P WILMSHURST, D J COLTART, \\ B S JENKINS, M M WEBB-PEPLOE
}

From the Departments of Cardiology and Medicine, St Thomas's Hospital, London

SUMMARY Left ventricular pressure, cardiac output, coronary sinus blood flow, and myocardial substrate extraction were measured in 10 patients with congestive (dilated) cardiomyopathy and in a control group of nine patients investigated for chest pain who proved to have no angiographic or metabolic evidence of ischaemic heart disease. Haemodynamic and angiographic measurements confirmed that the patients with cardiomyopathy had severe left ventricular disease. Coronary sinus blood flow and myocardial oxygen consumption were greater in the patients with cardiomyopathy, but were similar in the two groups when normalised for ventricular mass. Efficiency, estimated from the oxygen cost of external work, was grossly reduced in the cardiomyopathy group. No major differences in substrate extraction were demonstrated between the groups. Myocardial lactate production was not observed in any patient with cardiomyopathy. Free fatty acid and glycerol release were observed in several control subjects but in none of the patients with cardiomyopathy.

Measurements were repeated during pacing in five of the cardiomyopathy group and in each of the control subjects. The latter showed a normal response to pacing, whereas of the former, four sustained increases in end-diastolic pressure, two showed large reductions in both cardiac output and coronary flow, and only one increased coronary flow during pacing. Despite the failure of coronary flow to increase, lactate extraction remained high.

These results show that anaerobic carbohydrate metabolism is not an important energy source for the myopathic heart and suggest that ischaemia does not contribute to poor left ventricular function. No gross abnormality of oxidative metabolism was identified, implying that low efficiency lay in the poor contractile performance of the myopathic heart.

Congestive, or dilated, cardiomyopathy is a descriptive diagnosis attached to those patients with a primary disorder of cardiac muscle which results in ventricular dilatation, little if any hypertrophy, and reduced ejection. ${ }^{2}$ Investigation rarely yields the aetiology, and microscopical examination of endomyocardial biopsy specimens usually demonstrates non-specific muscle damage. ${ }^{34}$ Microchemical analysis of biopsy material has shown conspicuously raised levels of cytosol lactate dehydrogenase, 5 though this is not a specific marker for the disease, as moderately increased concentrations are found in patients with poor ventricular function secondary to valvular disease. ${ }^{5}$ The significance of this finding is uncertain, but because there have been occasional reports of myocardial lactate production in congestive car-

Accepted for publication 9 October 1981 diomyopathy 67 it has been suggested that the increased lactate dehydrogenase levels reflect the importance of anaerobic carbohydrate metabolism as an energy source for the myopathic heart. ${ }^{5}$

We have measured haemodynamics, coronary blood flow, and myocardial substrate extraction in 10 patients with severe congestive cardiomyopathy, and in a control group of nine patients investigated for chest pain in whom no cardiac abnormality was found. This study was undertaken to investigate the relation between cardiac work and energy consumption and to identify any abnormality of substrate extraction by the myopathic heart.

\section{Patients and methods}

Two groups of patients were studied; 10 patients who had clinical evidence of heart failure thought to result from congestive cardiomyopathy, and nine patients 
without heart failure who were under investigation for disabling chest pain. The procedure was approved by the hospital ethical committee, and each patient gave written consent.

All studies were performed in the morning after an overnight fast. Digoxin and diuretics were continued in the cardiomyopathy group until the time of study, but in the chest pain group beta-blocking drugs were stopped 48 hours beforehand. Premedication was with atropine $0.3 \mathrm{mg}$ and diazepam $10 \mathrm{mg}$ intramuscularly. At the same time heparin (45 units $/ \mathrm{kg}$ ) was given intravenously to minimise the effect of a subsequent dose of heparin upon free fatty acid concentrations. ${ }^{8}$ Right and left heart catheterisation was performed via the right femoral vein and artery. Immediately after arterial catheterisation a second dose of heparin (45 units $/ \mathrm{kg}$ ) was administered. After routine pressure measurements and coronary arteriography, a Ganz catheter was advanced into the coronary sinus via a left antecubital vein, and its position confirmed by injection of contrast. Cold saline was injected into the right atrium to ensure that the dilution thermistor was unaffected by reflux of atrial blood. 9 Using the long sheath technique ${ }^{10}$ a catheter tip micromanometer (either a Telco MM52 or No. 5 Millar) was positioned in the body of the left ventricle. In each of the nine patients with chest pain and in four of the patients with cardiomyopathy the retrograde aortic route was used, but in six patients with cardiomyopathy the catheter was positioned transseptally. Cardiac output was measured by dye dilution using a Schwarzer Swan-Ganz catheter positioned in the pulmonary artery, or (in four patients with cardiomyopathy) a CME velocity probe positioned in the ascending aorta.

No measurement were made for at least 20 minutes after coronary arteriography. Left ventricular pressure, cardiac output, and coronary sinus flow were measured, and left ventricular and coronary sinus blood were sampled. In each of the nine patients with chest pain, and in five of the cardiomyopathy group, measurements and samples were repeated during incremental coronary sinus pacing. Left ventricular cineangiography was performed at the end of the study.

The micromanometer and thermistor signals were displayed on a Cambridge 12 channel recorder, and stored on tape. Max $\mathrm{dP} / \mathrm{dt}$ was derived by an electronic differentiator or by computer, and $\mathrm{KVmax}$ was calculated from developed pressure ${ }^{11}$ using either an electronic processor ${ }^{12}$ or a computer. Mean left ventricular systolic pressure was derived by planimetric integration, or, when pressure and flow signals were measured simultaneously, by computer analysis ${ }^{13}$ Green dye curves were analysed by an IVH 3 cardiac output computer. When a velocity probe was used, cardiac output was calculated as mean flow velocity derived from integration of the velocity signal, multiplied by aortic cross-sectional area estimated by echocardiography or aortography. Coronary sinus blood flow was measured by constant infusion thermodilution. ${ }^{14}$ Using a computer-light pen system previously described, 12 the right anterior oblique view of the left ventricular cineangiogram was analysed to yield volume, ejection fraction, and mass.

The oxygen content of heparinised blood samples was measured upon a LEX- $0_{2}$ CON TL. Blood was added to an aliquot of perchloric acid for subsequent estimation of concentrations of lactate and pyruvate, ${ }^{15}$ hydroxybutyrate, and acetoacetate, ${ }^{16}$ and glycerol. ${ }^{17}$ For measurement of free fatty acids ${ }^{18}$ blood was added to sequestrine tubes and centrifuged. All samples were immediately put on ice, and stored at $-20^{\circ} \mathrm{C}$.

Myocardial oxygen consumption was calculated as coronary sinus blood flow multiplied by the difference between arterial and coronary sinus oxygen content. The extraction of a substrate is the difference in concentration between arterial and coronary sinus blood (A-V), and extraction ratio, that difference expressed as a percentage of arterial concentration $\left(\frac{A-y}{A} \mid \%\right.$. The oxygen extraction ratio of a substrate is defined as the amount of oxygen required to catabolise completely the amount of that substrate extracted expressed as a percentage of total oxygen extraction.

Myocardial efficiency was estimated using Bing's formula ${ }^{19}$ :

$$
\begin{aligned}
& \text { efficiency }=\frac{\mathrm{LV} \text { minute work }(\mathrm{kg} \mathrm{m} / \mathrm{min})}{\begin{array}{l}
\text { Myocardial oxygen consumption } \\
(\mathrm{ml} / \mathrm{min})
\end{array}} \\
& 2.059 \times 0.806(\text { normal }=40 \%)
\end{aligned}
$$

Values are expressed as mean \pm standard error. Student's $t$ test and linear regression are used where appropriate, and $p<0.05$ is considered significant.

\section{Results}

The diagnosis of congestive cardiomyopathy was confirmed in our 10 patients. Each had a dilated, poorly contracting left ventricle, normal coronary arteriograms and, with the exception of mild subvalvar mitral regurgitation, normal cardiac valves. The aetiology of myocardial damage was not identified in any patient. Two patients (cases 3 and 8) had a history suggestive of a preceding viral illness, but this was not confirmed by serology. One patient (case 1) had been a heavy drinker for many years.

Each of the nine patients investigated for chest pain (control group) had angiographically normal coronary arteries, and did not develop angina, electrocardiographic abnormalities, or produce lactate 
during pacing. Basal haemodynamics and quantitative left ventricular cineangiography were normal in these patients.

BASAL HAEMODYNAMICS (Tables 1 and 2)

Basal heart rate was $99 \pm 8$ beats/min in the patients with cardiomyopathy and $86 \pm 6$ beats/min in the control subjects (NS). Cardiac index, left ventricular systolic pressure, minute work, $\max \mathrm{dP} / \mathrm{dt}, \mathrm{KVmax}$, and ejection fraction were significantly lower, and end-diastolic volume index and end-diastolic pressure significantly higher in the cardiomyopathy group than in the controls. Coronary sinus blood flow and myocardial oxygen consumption were increased in the patients with cardiomyopathy compared with the control subjects and, as their left ventricular minute work was low, calculated efficiency was grossly reduced. None of the patients with cardiomyopathy had severe hypertrophy, though end-diastolic left ventricular free wall thickness, $0.93 \pm 0.06 \mathrm{~cm}$, was greater than in the control subjects, $0.69 \pm 0.04 \mathrm{~cm}(\mathrm{p}<0.05)$. Because of this small increase in wall thickness and the large increases in cavity dimensions, left ventricular mass was significantly greater in the cardiomyopathy than in the control group. Coronary sinus blood flow and myocardial oxygen consumption normalised for ventricular mass were similar in the two groups.

Table 1 Resting haemodynamics in cardiomyopathy and control group

\begin{tabular}{|c|c|c|c|c|c|c|c|c|c|}
\hline $\begin{array}{l}\text { Case } \\
\text { No. }\end{array}$ & $\begin{array}{l}\text { Age } \\
\text { (y) }\end{array}$ & Sex & $\begin{array}{l}C I \\
\left(I / \min \text { per } m^{2}\right)\end{array}$ & $\begin{array}{l}L V S P \\
(m m H g)\end{array}$ & $\begin{array}{l}\text { LVEDP } \\
(\mathrm{mmHg})\end{array}$ & $\begin{array}{l}K V \max \\
\left(s^{-1}\right)\end{array}$ & $\begin{array}{l}\operatorname{Max} d P / d t \\
(m m H g / s)\end{array}$ & $\begin{array}{l}L V E D V I \\
\left(m 1 / m^{2}\right)\end{array}$ & $E F$ \\
\hline $\begin{array}{c}\text { Cardior } \\
1 \\
2 \\
3 \\
4 \\
5 \\
6 \\
7 \\
8 \\
9 \\
10\end{array}$ & $\begin{array}{c}\text { pathy } \\
46 \\
49 \\
18 \\
38 \\
61 \\
41 \\
38 \\
18 \\
42 \\
30\end{array}$ & $\begin{array}{l}(\mathrm{n}= \\
\mathrm{M} \\
\mathrm{M} \\
\mathrm{M} \\
\mathrm{M} \\
\mathrm{M} \\
\mathrm{M} \\
\mathrm{F} \\
\mathrm{M} \\
\mathrm{M} \\
\mathrm{M}\end{array}$ & $\begin{array}{l}1.52 \\
1.34 \\
0.80 \\
1.97 \\
1.68 \\
2.02 \\
1.80 \\
1.24 \\
2.18 \\
1.33\end{array}$ & $\begin{array}{r}84 \\
97 \\
72 \\
84 \\
90 \\
80 \\
120 \\
83 \\
100 \\
77\end{array}$ & $\begin{array}{r}16 \\
28 \\
18 \\
10 \\
7 \\
15 \\
17 \\
28 \\
6 \\
23\end{array}$ & $\begin{array}{l}80 \\
89 \\
94 \\
40 \\
69 \\
43 \\
50 \\
62 \\
68 \\
81\end{array}$ & $\begin{array}{r}997 \\
925 \\
629 \\
660 \\
1145 \\
920 \\
900 \\
609 \\
1200 \\
579\end{array}$ & $\begin{array}{l}218 \\
228 \\
310 \\
171 \\
201 \\
225 \\
100 \\
395 \\
121 \\
275\end{array}$ & $\begin{array}{l}0.25 \\
0.24 \\
0.02 \\
0.20 \\
0.23 \\
0.22 \\
0.30 \\
0.12 \\
0.39 \\
0.17\end{array}$ \\
\hline $\begin{array}{l}\text { Mean } \\
\text { SEM }\end{array}$ & $\begin{array}{r}38 \cdot 1 \\
4 \cdot 2\end{array}$ & & $\begin{array}{l}1.59^{\star} \\
0.13\end{array}$ & $\begin{array}{c}88 \cdot 7^{\star} \\
4 \cdot 4\end{array}$ & $\begin{array}{r}17^{\star} \\
2 \cdot 5\end{array}$ & $\begin{array}{c}67^{\star} \\
6\end{array}$ & $\begin{array}{c}856^{\star} \\
72\end{array}$ & $\begin{array}{c}224^{\star} \\
31\end{array}$ & $\begin{array}{l}0.21^{\star} \\
0.04\end{array}$ \\
\hline $\begin{array}{l}\text { Control } \\
\text { Mean } \\
\text { SEM }\end{array}$ & $\begin{array}{r}u p(\mathrm{n} \\
46.2 \\
5.1\end{array}$ & & $\begin{array}{l}3.07 \\
0.32\end{array}$ & $\begin{array}{r}124 \\
8\end{array}$ & $\begin{array}{l}6.3 \\
2.0\end{array}$ & $\begin{array}{c}91.8 \\
5\end{array}$ & $\begin{array}{r}1527 \\
58\end{array}$ & $\begin{array}{r}59 \\
4\end{array}$ & $\begin{array}{l}0.66 \\
0.016\end{array}$ \\
\hline
\end{tabular}

${ }^{\star} p<0.01$ when cardiomyopathy and control group are compared

CI, cardiac index; LVSP, left ventricular systolic pressure; LVEDP, left ventricular end-diastolic pressure; LVEDVI, left ventricular end-diastolic volume index; EF, ejection fraction.

Table 2 Resting haemodynamics in cardiomyopathy and control groups

\begin{tabular}{|c|c|c|c|c|c|c|c|}
\hline $\begin{array}{l}\text { Case } \\
\text { No. }\end{array}$ & $\begin{array}{l}\text { CSF } \\
\text { (ml/min) }\end{array}$ & $\begin{array}{l}M \mathrm{VO}_{2} \\
\text { (ml/min) }\end{array}$ & $\begin{array}{l}L V M W \\
(k g \text { m/min })\end{array}$ & $\begin{array}{l}\text { Efficiency } \\
(\%)\end{array}$ & $\begin{array}{l}L V \text { mass } \\
(G)\end{array}$ & $\begin{array}{l}C S F / 100 g \\
(\mathrm{ml} / \mathrm{min})\end{array}$ & $\begin{array}{l}\mathrm{MVO}_{2} / 100 \mathrm{~g} \\
\text { (ml/min) }\end{array}$ \\
\hline $\begin{array}{c}\text { Cardion } \\
1 \\
2 \\
3 \\
4 \\
5 \\
6 \\
7 \\
8 \\
9 \\
10\end{array}$ & $\begin{array}{c}y \text { group } \\
213 \\
183 \\
171 \\
420 \\
174 \\
392 \\
289 \\
142 \\
211 \\
155\end{array}$ & $\begin{array}{l}19.0 \\
15.6 \\
35.2 \\
48.3 \\
32.0 \\
52.9 \\
35.0 \\
21.3 \\
26.8 \\
21.7\end{array}$ & $\begin{array}{l}2.50 \\
2.23 \\
0.80 \\
2.69 \\
2.87 \\
2.99 \\
3.07 \\
0.88 \\
4.01 \\
0.83\end{array}$ & $\begin{array}{l}7.4 \\
8.6 \\
1.4 \\
3.4 \\
5.4 \\
5.3 \\
5.3 \\
1.6 \\
9.0 \\
2.3\end{array}$ & $\begin{array}{l}291 \\
216 \\
315 \\
390 \\
222 \\
340 \\
181 \\
190 \\
248 \\
365\end{array}$ & $\begin{array}{r}73 \\
85 \\
54 \\
108 \\
78 \\
115 \\
160 \\
75 \\
85 \\
43\end{array}$ & $\begin{array}{r}6.5 \\
7 \cdot 2 \\
11.2 \\
12.3 \\
14.4 \\
15.6 \\
19.3 \\
11.2 \\
10.8 \\
5.9\end{array}$ \\
\hline $\begin{array}{l}\text { Mean } \\
\text { SEM }\end{array}$ & $\begin{array}{c}235^{\star} \\
31\end{array}$ & $\begin{array}{c}30.8^{\star} \\
3.9\end{array}$ & $\begin{array}{l}2.29 \star \\
0.35\end{array}$ & $\begin{array}{l}4.8^{\star} \\
0.9\end{array}$ & $\begin{array}{c}276^{\star} \\
24\end{array}$ & $\begin{array}{l}88 \\
11\end{array}$ & $\begin{array}{r}11 \cdot 4 \\
1 \cdot 3\end{array}$ \\
\hline $\begin{array}{l}\text { Control } \\
\text { Mean } \\
\text { SEM }\end{array}$ & $\begin{array}{r}120 \\
15\end{array}$ & $\begin{array}{r}11.6 \\
1.6\end{array}$ & $\begin{array}{l}6.99 \\
0.63\end{array}$ & $\begin{array}{r}39.4 \\
4.0\end{array}$ & $\begin{array}{r}121 \\
13\end{array}$ & $\begin{array}{l}99 \\
10\end{array}$ & $\begin{array}{l}9.6 \\
0.8\end{array}$ \\
\hline
\end{tabular}

$\star<0.01$ when cardiomyopathy and control group are compared

$\mathrm{CSF}$, coronary sinus blood flow, $\mathrm{MVO}_{2}$, myocardial oxygen group uptake; LVMW, left ventricular minute work, CSF/100g, coronary sinus blood flow/ $100 \mathrm{~g}$ myocardium; $\mathrm{MVO}_{2} / 100 \mathrm{~g}$, oxygen consumption/100g myocardium. 


\section{BASAL METABOLIC RESULTS}

The arterial and coronary venous concentrations, extraction, extraction ratio, and oxygen extraction ratio of the six substrates measured are listed in Table 3.

The high mean arterial lactate concentration in the cardiomyopathy group was largely the result of concentrations of 2.705 and $1.379 \mathrm{mmol} / 1$ in cases 3 and 8 , both of whom had a very low cardiac output. Myocardial lactate production was not observed in either group. Though lactate extraction and oxygen extraction ratio were significantly greater in the cardiomyopathy than in the control group, these differences were caused in part by greater arterial lactate concentrations. Extraction ratio did not differ significantly between the two groups.

No differences were shown between the two groups in concentrations or extraction of pyruvate, hydroxybutyrate, or acetoacetate.

Free fatty acid extraction was positive in each of the patients with cardiomyopathy, whereas two of the control subjects had negative values. Extraction and extraction ratio were significantly greater in the cardiomyopathy than in the control group and these differences were still significant when the two controls with negative values were excluded from analysis.

Glycerol extraction was positive in each of the six patients with cardiomyopathy, but glycerol release was observed in six of the nine control subjects; consequently glycerol extraction and extraction ratio were significantly greater in the cardiomyopathy group.
The total of the oxygen extraction ratios of the substrates measured was $130 \% \pm 18$ in the cardiomyopathy group and $86 \% \pm 19$ in the control group (NS).

\section{Effects of pacing}

The results at the highest pacing rate are listed in Table 4. Pacing was without effect upon end-diastolic pressure or indices of contractility in the cardiomyopathy group, whereas in the control group end-diastolic pressure decreased and $\max \mathrm{dP} / \mathrm{dt}$ increased significantly. Coronary flow increased in each of the control subjects, but rose substantially in only one patient with cardiomyopathy; in two it changed little, and in two it decreased. Cardiac output decreased on pacing in both the patients who sustained large reductions in coronary flow.

Myocardial lactate production was not seen in either group during pacing, even in the two patients who sustained reductions in coronary flow.

\section{Discussion}

Although all nine patients in the control group had a history of chest pain, their normal haemodynamics and coronary arteriograms, and the failure of pacing to provoke pain or myocardial lactate production allow them to be regarded as normal control subjects.

Each of the patients in the cardiomyopathy group had reached an advanced stage of their disease. Though it is likely that within the group there were

Table 3 Basal metabolic results

\begin{tabular}{|c|c|c|c|c|c|}
\hline & $\underset{(m M / l)}{A}$ & $\begin{array}{l}C S \\
(m M / l)\end{array}$ & $\begin{array}{l}A-V \\
(m M / l)\end{array}$ & $\begin{array}{l}A-V \mid A \\
(\%)\end{array}$ & $\begin{array}{l}O_{2 E R} \\
(\%)\end{array}$ \\
\hline \multicolumn{6}{|l|}{ Lacate } \\
\hline $\begin{array}{l}\operatorname{COCM}(n=10) \\
\text { Controls }(n=9)\end{array}$ & $\begin{array}{l}0.966 \pm 0.216 \\
0.562 \pm 0.066 \\
\text { NS }\end{array}$ & $\begin{array}{l}0.648 \pm 0.160 \\
0.407 \pm 0.044 \\
\text { NS }\end{array}$ & $\begin{array}{l}0.347 \pm 0.069 \\
0.134 \pm 0.032 \\
p<0.05\end{array}$ & $\begin{array}{l}35 \cdot 7 \pm 3 \cdot 9 \\
27 \cdot 5 \pm 3 \cdot 6 \\
\text { NS }\end{array}$ & $\begin{array}{l}19.9 \pm 3.4 \\
11 \cdot 1 \pm 2.2 \\
p<0.05\end{array}$ \\
\hline \multirow[t]{2}{*}{$\begin{array}{l}\text { Pyruvate } \\
\text { COCM }(n=8) \\
\text { Controls }(n=9)\end{array}$} & $\begin{array}{l}0.057 \pm 0.013 \\
0.044 \pm 0.010\end{array}$ & $\begin{array}{l}0.036 \pm 0.008 \\
0.036 \pm 0.009\end{array}$ & $\begin{array}{l}0.0209 \pm 0.006 \\
0.0179 \pm 0.010\end{array}$ & $\begin{array}{l}32 \cdot 2 \pm 7 \cdot 8 \\
20 \cdot 0 \pm 9 \cdot 1\end{array}$ & $\begin{array}{l}1.2 \pm 0.2 \\
0.6 \pm 0.2\end{array}$ \\
\hline & NS & NS & NS & NS & NS \\
\hline \multirow{2}{*}{$\begin{array}{l}\text { Hydroxybutyrate } \\
\text { COCM }(\mathbf{n}=7) \\
\text { Controls }(\mathbf{n}=9)\end{array}$} & & & & & \\
\hline & $\begin{array}{l}0.156 \pm 0.038 \\
0.188 \pm 0.053 \\
\text { NS }\end{array}$ & $\begin{array}{l}0.091 \pm 0.021 \\
0.121 \pm 0.035 \\
\text { NS }\end{array}$ & $\begin{array}{l}0.065 \pm 0.019 \\
0.066 \pm 0.19 \\
\text { NS }\end{array}$ & $\begin{array}{l}42 \cdot 3 \pm 6 \cdot 1 \\
33 \cdot 6 \pm 5 \cdot 5 \\
\text { NS }\end{array}$ & $\begin{array}{l}5 \cdot 6 \pm 1 \cdot 0 \\
6 \cdot 9 \pm 2 \cdot 1 \\
\text { NS }\end{array}$ \\
\hline $\begin{array}{l}\text { Acetoacetate } \\
\text { COCM }(\mathbf{n}=7) \\
\text { Controls }(\mathbf{n}=9)\end{array}$ & $\begin{array}{l}0.105 \pm 0.025 \\
0.089 \pm 0.021 \\
\text { NS }\end{array}$ & $\begin{array}{l}0.053 \pm 0.028 \\
0.046 \pm 0.026 \\
\text { NS }\end{array}$ & $\begin{array}{l}0.052 \pm 0.017 \\
0.043 \pm 0.014 \\
\text { NS }\end{array}$ & $\begin{array}{l}45 \cdot 1 \pm 8 \cdot 7 \\
42 \cdot 6 \pm 3 \cdot 9 \\
\text { NS }\end{array}$ & $\begin{array}{l}3.8 \pm 1.6 \\
3.5 \pm 0.8 \\
N S\end{array}$ \\
\hline $\begin{array}{l}\text { Free fatty acids } \\
\operatorname{COCM}(n=9) \\
\text { Controls }(n=9)\end{array}$ & $\begin{array}{l}0.753 \pm 0.114 \\
0.958 \pm 0.149 \\
\text { NS }\end{array}$ & $\begin{array}{l}0.539 \pm 0.080 \\
0.894 \pm 0.167 \\
\text { NS }\end{array}$ & $\begin{array}{l}0.225 \pm 0.037 \\
0.063 \pm 0.054 \\
p<0.05\end{array}$ & $\begin{array}{l}30.2 \pm 2.5 \\
7 \cdot 2 \pm 7 \cdot 1 \\
p<0.01\end{array}$ & $\begin{array}{l}102 \pm 18 \\
61 \cdot 8 \pm 18 \star \\
\text { NS }\end{array}$ \\
\hline $\begin{array}{l}\text { Glycerol } \\
\text { COCM }(n=6) \\
\text { Controls }(n=9)\end{array}$ & $\begin{array}{l}0.076 \pm 0.014 \\
0.064 \pm 0.001 \\
\text { NS }\end{array}$ & $\begin{array}{l}0.056 \pm 0.014 \\
0.074 \pm 0.007 \\
\text { NS }\end{array}$ & $\begin{array}{l}0.020 \pm 0.004 \\
-0.010 \pm 0.007 \\
p<0.01\end{array}$ & $\begin{array}{l}29.2 \pm 5.8 \\
-12.6 \pm 8.6 \\
p<0.01\end{array}$ & - \\
\hline
\end{tabular}

Values expressed as mean \pm SEM. A, arterial concentration; CS, coronary sinus concentration; NS, not significant; A-V, extraction; $A-V / A$, extraction ratio; $\mathrm{O}_{2} E R$, oxygen extraction ratio.

$\star$ Excluding negative values. 
Table 4 Effects of pacing

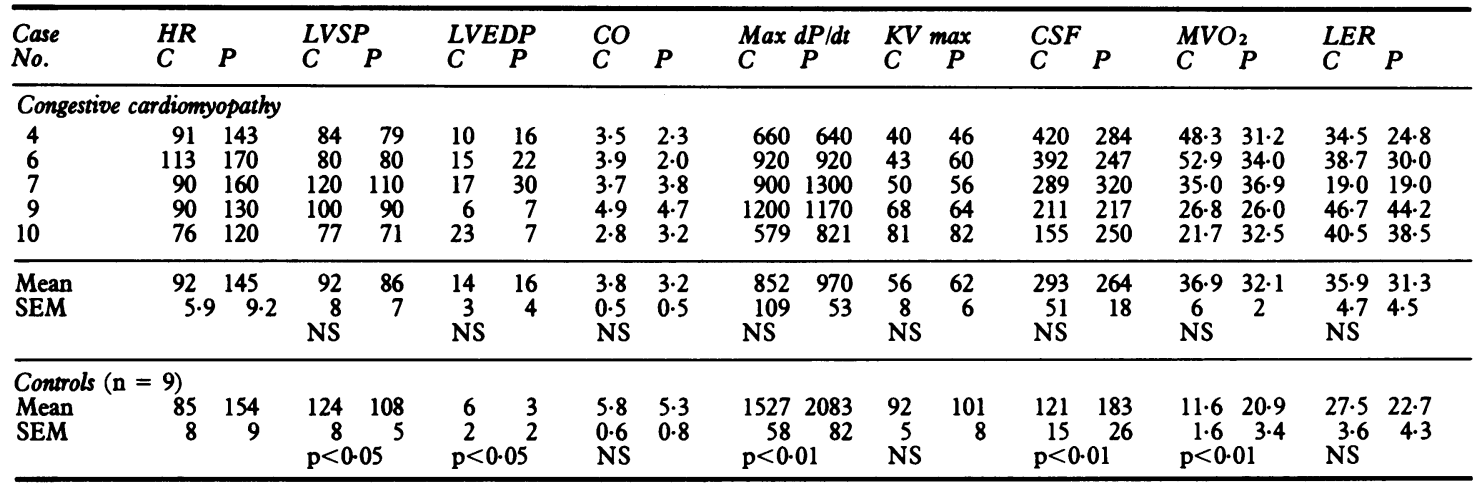

HR, heart rate; LVSP, peak left ventricular systolic pressure (mmHg);LVEDP, left ventricular end-diastolic pressure (mmHg); $\mathrm{CSF}$, coronary sinus blood flow ( $\mathrm{ml} / \mathrm{min}$ ); $\mathrm{MVO}_{2}$, myocardial oxygen consumption (ml/min); LER, lactate extraction ratio; $C$, control state; $\mathbf{P}$, pacing; NS, not significant.

different causes of myocardial damage, the 10 patients were haemodynamically and metabolically so similar it is legitimate to treat them as a homogeneous group.

The efficiency of the heart can be estimated by relating external work to myocardial oxygen consumption. ${ }^{19}$ The mean value of $39 \%$ in the control group is in close agreement with previous estimates of the efficiency of the normal heart. ${ }^{19}$ Each of the patients with cardiomyopathy had low efficiency, and their mean value of $4 \%$ emphasises the severity of the disturbance of myocardial energetics. The oxygen consumption of the ventricle is determined largely by muscle tension, ${ }^{20}$ dependent upon both pressure and volume, while external work is determined by the extent of muscle shortening against this tension (load). Dilatation therefore increases both myocardial oxygen consumption and the load opposing shortening. When muscle function is poor, shortening against load is reduced, so efficiency will be low, and will decrease further as energy consumption and load increase with further dilatation. That the failing dilated heart operates against excessive load is suggested by the large improvement in efficiency during infusion of sodium nitroprusside. ${ }^{21}$ Dilatation and excessive load are logical consequences of poor contractile function, and efficiency may be low when oxidative metabolism and the oxygen cost of tension development are normal.

The normal ventricle hypertrophies without dilating in response to chronic pressure overload, and the increased wall thickness maintains wall stress within normal limits. ${ }^{22}$ When a ventricle of a given mass dilates, the increase in cavity dimensions and decreased wall thickness will increase stress, which may stimulate hypertrophy. Though none of our patients had gross hypertrophy, their end-diastolic wall thickness was greater than in the control subjects and their greater myocardial oxygen consumption was related largely to increased mass.

The normal heart derives its energy supply from the oxidation of free fatty acids, lactate, and glucose, with smaller contributions from the oxidation of pyruvate and ketone bodies. ${ }^{23}$ The pattern of substrate extraction in both groups of patients was broadly similar to results reported for the normal heart. $23-25$

Myocardial lactate extraction was high in each of the patients with cardiomyopathy, and myocardial lactate production was not observed in either group. Lactate extraction and oxygen extraction ratio were significantly greater in the cardiomyopathy group than in controls. These differences may have been the result in part of the high arterial lactate concentrations observed in several patients in the cardiomyopathy group. In addition, the high arterial free fatty acid concentrations in several control subjects would be expected to inhibit myocardial lactate extraction. ${ }^{26}$ The high lactate extraction in the cardiomyopathy group is consistent with the increased concentration of cytosol lactate dehydrogenase found in ventricular biopsy specimens taken from patients with this condition, ${ }^{5}$ though comparable lactate extraction ratios are found in patients with hypertrophic obstructive cardiomyopathy ${ }^{27}$ where levels of the enzyme are normal. 5 Moderate increases in lactate dehydrogenase have been reported in patients with poor left ventricular function secondary to chronic valvular disease. ${ }^{5}$ The low cardiac output of severe heart failure tends to increase arterial lactate concentration, so that increased cytosol lactate dehydrogenase levels may be a nonspecific adaptation allowing the myocardium to metabolise the available lactate.

There have been occasional reports of lactate production by the myopathic heart, ${ }^{67}$ and it has been suggested that anaerobic carbohydrate metabolism is an 
important energy source in this condition. ${ }^{5}$ As myocardial lactate production was not observed in our patients it is unlikely that anaerobic metabolism contributed significantly to energy requirements, or that ischaemia was responsible for poor contractile function.

The study of myocardial free fatty acid metabolism is complicated by the activation of lipoprotein lipase by heparin. ${ }^{28}$ We believe that adequate anticoagulation is mandatory for left heart catheterisation, and all patients in this study received heparin. In a previous study we showed that intravenous heparin administered one hour before catheterisation effectively attenuates the rise in arterial free fatty acids after a subsequent dose of heparin, and that within 30 minutes of this second dose, given at the time of arterial catheterisation, arterial concentration returns to control levels. ${ }^{8}$ This regimen of two doses was used in this study.

Experiments with labelled palmitate have shown that in the normal heart there is myocardial lipolysis with release of free fatty acids into coronary venous blood. ${ }^{29}$ Free fatty acids extracted by the heart may be esterified rather than oxidised immediately, ${ }^{30}$ and free fatty acids derived from lipolysis may be oxidised. ${ }^{30}$ Thus, measured extraction may not reflect true uptake, and true uptake, if it were known, does not measure the rate of oxidation. In addition, when the arteriovenous concentration difference is narrow, small errors in measuring concentrations will have a large effect upon estimated extraction. For these reasons the finding of significantly greater free fatty acid extraction and extraction ratio in the cardiomyopathy compared with the control group should be viewed with caution.

Despite these difficulties it is of great interest that release of neither free fatty acids nor glycerol was observed in the patients with cardiomyopathy, whereas free fatty acid release was found in two, and glycerol release in six of the nine control subjects. Release of free fatty acids and glycerol are also common in patients with coronary artery disease ${ }^{831}$ and hypertrophic obstructive cardiomyopathy. ${ }^{27}$ It cannot be concluded from this study that free fatty acid metabolism is abnormal in congestive cardiomyopathy, but this problem merits further investigation with labelled free fatty acids.

Because patients with congestive cardiomyopathy improve clinically during long-term administration of beta-blocking drugs ${ }^{32} 33$ and relapse when they are withdrawn, ${ }^{34}$ catecholamine excess or sympathetic overactivity have been suggested as pathogenic mechanisms. ${ }^{33} 34$ Acutely catecholamines increase myocardial lipolysis ${ }^{35}$ and the arterial concentration and myocardial oxidation of free fatty acids, ${ }^{36}$ and inhibit pyruvate dehydrogenase. ${ }^{37}$ The relatively low arterial free fatty acid concentrations, the absence of glycerol release, and the consistently high lactate extraction ratios in our patients do not suggest catecholamine excess. It is unlikely that the beneficial effect of beta-blocking drugs is the result either of changes in myocardial substrate extraction or relief of ischaemia.

In the control group the haemodynamic changes during pacing were normal, ${ }^{38} 39$ whereas in the five patients with cardiomyopathy who were paced, enddiastolic pressure tended to rise and indices of contractility did not increase significantly. Coronary sinus blood flow increased substantially with heart rate in each control subject, but in only one patient with cardiomyopathy. Failure to increase flow with heart rate implies that the coronary vasculature is near maximal dilatation at rest. Under these circumstances coronary flow is critically dependent upon cardiac output and the length of diastole; in both of the patients who sustained reductions of coronary flow cardiac output decreased on pacing. Failure to augment coronary flow as heart rate increases in patients with severe aortic stenosis ${ }^{40}$ or hypertrophic obstructive cardiomyopathy ${ }^{27}$ is associated with myocardial lactate production. Lactate extraction remained high in each of our five patients. Thus, the myopathic heart does not resort to anaerobic metabolism even during the stress of pacing.

This study shows that the overall efficiency of the heart is severely reduced in congestive cardiomyopathy. Though there were small differences in substrate extraction between the two groups, no gross abnormality of oxidative metabolism was found in patients with congestive cardiomyopathy, suggesting that low efficiency lies in poor mechanical function rather than in deficient energy supply.

\section{References}

1 Goodwin JF, Oakley CM. The cardiomyopathies. $\mathrm{Br}$ Heart f 1972; 34: 545-52.

2 Goodwin JF. Congestive and hypertrophic cardiomyopathies. A decade of study. Lancet 1970; i: 731-9.

3 Davies MJ, Brooksby IAB, Jenkins BS, et al. Left ventricular endomyocardial biopsy II: the value of light microscopy. Cathet Cardiovasc Diagn 1977; 3: 123-30.

4 Davies MJ, Kenedy S, Brooksby IAB, et al. Left ventricular biopsy III: ultrastructural characteristics of cardiomyopathy and cardiac hypertrophy with good or poor ventricular function. Cathet Cardiovasc Diagn 1977; 3: 131-7.

5 Peters TJ, Wells G, Oakley CM, et al. Enzymic analysis of endomyocardial biopsy specimens from patients with cardiomyopathies. Br Heart f 1977; 39: 1333-9.

6 Brachfeld N. Ischemic myocardial metabolism and cell necrosis. Bull NY Acad Med 1974; 50: 261-93.

7 Klassen GA, Tanser PH, Marpole D, Agarwal JB. Adaptation of the coronary circulation to primary myocardial 
disease. In Dhalla NS, ed. Myocardial metabolism. (Recent advances in studies on cardiac structure and metabolism. vol.3) Baltimore: University Park Press, 1973: 497-506.

8 Thompson DS, Naqvi N, Juul SM, Coltart DJ, Jenkins BS, Webb-Peploe MM. Haemodynamic and metabolic effects of atenolol in patients with angina pectoris. $\mathrm{Br}$ Heart f 1980; 43: 668-79.

9 Mathey DG, Chatterjee K, Tyberg JV, Lekven J, Brundage B, Parmely WW. Coronary sinus reflex: a source of error in the measurement of thermodilution coronary sinus flow. Circulation 1978; 57: 778-86.

10 Brooksby IAB, Swanton RH, Jenkins BS, Webb-Peploe $M M$. Long sheath technique for introduction of catheter tip micromanometer or endomyocardial bioptome into left or right heart. Br Heart $\mathcal{F}$ 1974; 36: 908-12.

11 Grossman W, Brooks H, Meister S, Sherman H, Dexter L. New technique for determining instantaneous myocardial force-velocity relations in the intact heart. Circ Res 1971; 28: 290-7.

, 12 Kolettis M, Jenkins BS, Webb-Peploe MM. Assessment of left ventricular function by indices derived from aortic flow velocity. $\mathrm{Br}$ Heart $\mathcal{F}$ 1976; 38: 18-31.

13 Malcolm AD, Stoate M, Houston BD, Williams BT, Webb-Peploe MM. Comprehensive computer-aided cardio-circulatory monitoring after open heart surgery and application in measurement of the effects of adrenaline. In: Astrow HG, Ripley KL, eds. Computers in cardiology. Proceedings of the 1977 conference. Long Beach: IEEE Computer Society, 1977: 67-77.

14 Ganz W, Tamura K, Marcus HS, Donoso R, Yoshida S, Swan HJC. Measurement of coronary sinus blood flow by continuous thermodilution in man. Circulation 1971; 44: 181-95.

15 Hohorst HJ, Kreutz FH, Bücher T. Metabolitgehalte und Metabolit-Konzentrationen in der Leber der Ratte. Biochem Z 1959; 332: 18-46.

16 Williamson DH, Mellanby J. Krebs AH. Enzymic determination of $\mathrm{D}(-) \beta$-Hydroxybutyric acid and aceto-acetic acid in blood. Biochem $\mathcal{F}$ 1962; 82: $90-6$.

17 Kreutz FH. Enzymatische Glycerinbestimmung. Klin Wochenschr 1962; 40: 362-3.

18 Carruthers M, Young DAB. Free fatty acid estimation by a semi-automated fluorometric method. Clin Chim Acta 1973; 49: 341-8.

19 Bing RJ Michal G. Myocardial efficiency. Ann NY Acad Sci 1959; 72: 555-8.

20 Braunwald E. Control of myocardial oxygen consumption: physiologic and clinical considerations. Am $\mathbf{f} \mathrm{Car}$ diol 1971; 27: 416-32.

21 Thompson DS, Juul SM, Wilmshurst P, et al. Effects of sodium nitroprusside upon cardiac work, efficiency, and substrate extraction in severe left ventricular failure. $\mathrm{Br}$ Heart $\mathcal{F}$ 1981; 46: 394-400.

22 Hood WP Jr., Rackley CE, Rolett EL. Wall stress in the normal and hypertrophied human left ventricle. Am $\mathfrak{f}$ Cardiol 1968; 22: 550-8.

23 Bing R. Cardiac metabolism. Physiol Rev 1965; 45: 171-213.

24 Bing RJ, Siegel A, Vitale A, et al. Metabolic studies on the human heart in vivo. I. Studies in carbohydrate metabolism of the human heart. Am $\mathcal{F}$ Med 1953; 15: 284-96.

25 Bing RJ, Siegel A, Ungar I, Gilbert M. Metabolism of the human heart II. Studies on fat, ketone and amino acid metabolism. Am $\mathcal{F}$ Med 1954; 16: 504-15.

26 Lassers BW, Wahlquist ML, Kaiser L, Carlson LA. Relationship in man between plasma free fatty acids and myocardial metabolism of carbohydrate substrates. Lancet 1971; ii: 448-50.

27 Thompson DS, Naqvi N, Juul SM, et al. Effects of propranolol on myocardial oxygen consumption, substrate extraction, and haemodynamics in hypertrophic obstructive cardiomyopathy. $\mathrm{Br} \mathrm{Heart} \mathcal{F}$ 1980; 44: 488-98.

28 Korn ED. Clearing factor; a heparin-activated lipoprotein lipase I. Isolation and characterization of the enzyme from the rat heart. $\mathcal{F}$ Biol Chem 1955; 215: 1-14.

29 Most AS, Brachfeld N, Gorlin R, Wahren J. Free fatty acid metabolism of the human heart at rest. $\mathcal{F}$ Clin Invest 1969; 48: 1177-88.

30 Zierler KL. Fatty acids as substrates for heart and skeletal muscle. Circ Res 1976; 38: 459-63.

31 Naqvi N, Thompson DS, Juul SM, Jenkins BS, WebbPeploe MM, Coltart DJ. Stimulation of myocardial lactate extraction by oxfenicine ( $\mathrm{L}$-hydroxyphenylglycine). Eur Heart $\mathcal{f}$ 1980; 1: 255-61.

32 Waagstein F, Hjalmarson A, Varnauskas E, Wallentin I. Effect of chronic beta-adrenergic receptor blockade in congestive cardiomyopathy. Br Heart $\mathcal{F}$ 1975; 37: 1022 36.

33 Swedberg K, Hjalmarson A, Waagstein F, Wallentin I. Beneficial effects of long-term beta-blockade in congestive cardiomyopathy. Br Hear $\mathcal{f}$ 1980; 44: 117-33.

34 Swedberg K, Hjalmarson A, Waagstein F, Wallentin I. Adverse effects of beta-blockade withdrawal in patients with congestive cardiomyopathy. $\mathrm{Br} \mathrm{Heart} \mathcal{F} 1980$; 44: $134-42$.

35 Lech JJ, Jesmok GL, Calvert DN. Effects of drugs and hormones on lipolysis in the heart. Fed Proc 1977; 36: 2000-8.

36 Simonsen S, Kjekshus JK. The effect of free fatty acids upon myocardial oxygen consumption during atrial pacing and catecholamine infusion in man. Circulation 1978; 58: 484-91.

37 Coore HG, Denton RM, Martin BR, Randle PJ. Regulation of adipose tissue pyruvate dehydrogenase by insulin and other hormones. Biochem $f$ 1971; 125: 115-27.

38 Linhart JW. Pacing induced changes in stroke volume in the evaluation of myocardial function. Circulation 1971; 43: 253-61.

39 Leighton RF, Zaron SJ, Robinson JL, Weissler AM. Effects of atrial pacing upon left ventricular performance in patients with heart disease. Circulation 1969; 40: 615 22.

40 Fallen EL, Elliot WC, Gorlin R. Mechanisms of angina in aortic stenosis. Circulation 1967; 36: 480-8.

Requests for reprints to $\mathrm{Dr} D \mathrm{~S}$ Thompson, Department of Cardiology, St Thomas's Hospital, London SE1 7EH. 